\title{
Erratum to: Natural Hazards \\ And Peoples in the Indian Ocean World
}

Greg Bankoff and Joseph Christensen

(C) The Editor(s) (if applicable) and The Author(s) 2016

G. Bankoff, J. Christensen (eds.), Natural Hazards and Peoples in the Indian Ocean World, DOI 10.1057/978-1-349-94857-4

\section{DOI 10.1057/978-1-349-94857-4_12}

The original version of the book contained errors which has been corrected. The corrections are given below:

\section{Chapter 5: Philippine Typhoons Since the Seventeenth Century}

- On p.122: The caption for Figure 5.1 should read 'Map 5.4. Areas vulnerable to storm surges, Philippines' [this caption appears incorrectly on p.127 under Map 5.4]

- On p.124: The caption for Figure 5.2 should read 'Fig. 5.1. Annual frequency of tropical cyclones crossing the Philippines (1948-2000). Source: This table was constructed from data provided by PAGASA on www.pagasa.dost.gov.ph'. [this caption appears incorrectly on p.122 under Fig. 5.1]

- On p.125: The caption for Figure 5.3 should read: 'Fig. 5.2. Annual tropical cyclone El Niño/La Niña frequency, 1880-1898. Source: Tropical cyclone data is based on the Report of the Philippine

(C) The Editor(s) (if applicable) and The Author(s) 2016 
Commission 1900, p. 292' [this caption appears incorrectly on p.124 under Fig. 5.2]

- On p.127: The caption for the figure appearing on this page, Map. 5.4, should read: 'Fig. 5.3. Frequency and intensity of Super Typhoons, 1600-2000. Based on an index compiled from PAGASA's records, Miguel Selga, Charts of Remarkable Typhoons in the Philippines 1902-1934, Miguel Selga, Catalogue of Typhoons 1348-1934 (Manila: Bureau of Printing, 1935) and archival records found in Spain and the Philippines' [this caption appears incorrectly on p.125 under Fig. 5.3]

- On p.125: For the figure shown on this page, the years (i.e. 18801898 ) should be shown consecutively on the horizontal axis.

- On p.126: The correct caption for this Figure is: 'Table 5. Number of typhoons affecting the Philippines from 1880 to 1999'.

Chapter 7: Emperor Tư Đức's 'Bad Weather': Interpreting Natural Disasters in Vietnam, 1847-1883

- On p.173: Fig 7.2 the original graph was removed and the revised graph is updated.

\section{$\underline{\text { FM }}$}

List of Figures and List of Maps are updated as per the above corrections. The updated original online version for this book can be found at http:// dx.doi.org/10.1057/978-1-349-94857-4 